\title{
Complex Oxides Based on Silver, Bismuth and Tungsten: Syntheses, Characterization and Photoelectrochemical Behavior
}

\section{DOI:}

10.1021/acs.jpcc.7b11924

\section{Document Version}

Accepted author manuscript

Link to publication record in Manchester Research Explorer

Citation for published version (APA):

Longo, C., Tayar Galante, M., Fitzmorris, R., Zhang, J. Z., Taylor, S. F. R., Mohapatra, J., Liu, J. P., Duarte, L. G. T. A., Hossain, M. K., Hardacre, C., \& Rajeshwar, K. (2018). Complex Oxides Based on Silver, Bismuth and Tungsten: Syntheses, Characterization and Photoelectrochemical Behavior. The Journal of Physical Chemistry C, 122(25). https://doi.org/10.1021/acs.jpcc.7b11924

\section{Published in:}

The Journal of Physical Chemistry C

\section{Citing this paper}

Please note that where the full-text provided on Manchester Research Explorer is the Author Accepted Manuscript or Proof version this may differ from the final Published version. If citing, it is advised that you check and use the publisher's definitive version.

\section{General rights}

Copyright and moral rights for the publications made accessible in the Research Explorer are retained by the authors and/or other copyright owners and it is a condition of accessing publications that users recognise and abide by the legal requirements associated with these rights.

\section{Takedown policy}

If you believe that this document breaches copyright please refer to the University of Manchester's Takedown Procedures [http://man.ac.uk/04Y6Bo] or contact uml.scholarlycommunications@manchester.ac.uk providing relevant details, so we can investigate your claim.

\section{OPEN ACCESS}




\section{Complex Oxides Based on Silver, Bismuth and Tungsten: Syntheses, Characterization and Photoelectrochemical Behavior}

Claudia Longo, Miguel Tayar Galante, Robert Fitzmorris, Jin Z. Zhang, Sarah

Frances Rebecca Taylor, Jeotikanta Mohapatra, Jie Ping Liu, Luis G.T.A. Duarte, Mohammad Kabir Hossain, Christopher Hardacre, and Krishnan Rajeshwar

J. Phys. Chem. C, Just Accepted Manuscript • DOI: 10.1021/acs.jpcc.7b11924 • Publication Date (Web): 08 Feb 2018

Downloaded from http://pubs.acs.org on February 8, 2018

\section{Just Accepted}

"Just Accepted" manuscripts have been peer-reviewed and accepted for publication. They are posted online prior to technical editing, formatting for publication and author proofing. The American Chemical Society provides "Just Accepted" as a service to the research community to expedite the dissemination of scientific material as soon as possible after acceptance. "Just Accepted" manuscripts appear in full in PDF format accompanied by an HTML abstract. "Just Accepted" manuscripts have been fully peer reviewed, but should not be considered the official version of record. They are citable by the Digital Object Identifier (DOI®). "Just Accepted" is an optional service offered to authors. Therefore, the "Just Accepted" Web site may not include all articles that will be published in the journal. After a manuscript is technically edited and formatted, it will be removed from the "Just Accepted" Web site and published as an ASAP article. Note that technical editing may introduce minor changes to the manuscript text and/or graphics which could affect content, and all legal disclaimers and ethical guidelines that apply to the journal pertain. ACS cannot be held responsible for errors or consequences arising from the use of information contained in these "Just Accepted" manuscripts. 


\author{
J.Phy.Chem.C \\ Manuscript ID: \\ Submitted: December 2017 \\ Revision Resubmitted: February 2018
}

Manuscript ID jp-2017-119248

\title{
Complex Oxides Based on Silver, Bismuth and Tungsten: Syntheses,
}

\section{Characterization and Photoelectrochemical Behavior}

\author{
C. Longo, ${ }^{1 *}$ M. T. Galante, ${ }^{1}$ R. Fitzmorris ${ }^{2}$, J. Z. Zhang ${ }^{2}$, S.F.R.Taylor ${ }^{3}$, J. Mohapatra, ${ }^{4}$ J. Ping Liu, ${ }^{4}$ L. \\ G.T.A. Duarte, ${ }^{1}$ M. K. Hossain, ${ }^{5}$ C. Hardacre, ${ }^{3}$ and K. Rajeshwar ${ }^{5 *}$ \\ ${ }^{1}$ Institute of Chemistry, University of Campinas - UNICAMP, PO box 6154, 13083-970, Campinas, SP, Brazil; \\ ${ }^{2}$ Department of Chemistry and Biochemistry, The University of California at Santa Cruz, Santa Cruz \\ ${ }^{3}$ School of Chemical Engineering and Analytical Science, University of Manchester, The Mill, Sackville Street, \\ Manchester M13 9PL United Kingdom \\ ${ }^{4}$ Department of Physics, The University of Texas at Arlington, Arlington, TX76019 \\ ${ }^{5}$ Department of Chemistry and Biochemistry, The University of Texas at Arlington, Arlington, TX76019
}

\begin{abstract}
Silver-containing complex oxides present interesting light absorption and electronic properties pointing to their applicability for solar fuels generation and environmental remediation. In this vein, the syntheses, characterization and photoelectrochemical properties of the Aurivillius oxide, $\mathrm{AgBiW} \mathrm{O}_{8}$ and a tri-phasic material: $\mathrm{AgBiW}_{2} \mathrm{O}_{8} / \mathrm{Bi}_{2} \mathrm{WO}_{6} / \mathrm{Ag}$ are described herein. From UV-Vis diffuse reflectance analysis, both oxides nanoparticles exhibited intense absorption at wavelengths $<455 \mathrm{~nm}$, with an additional band centered at $\sim 500 \mathrm{~nm}$ for the tri-phasic material, and attributed to surface plasmon resonance of the metallic Ag phase The tri-phasic material was further characterized by a variety of structural and spectroscopic probes, indicating a defect-rich crystalline structure. Voltammetric measurements were performed in the dark and under simulated solar irradiation with polarization at potentials more negative than the rest potential. Thin film electrodes of both materials showed p-type semiconductor behavior, with enhanced cathodic photocurrent in the presence of electron acceptors in aqueous media.
\end{abstract}

\footnotetext{
*Corresponding Authors

clalongo@iqm.unicamp.br; rajeshwar@uta.edu
} 


\section{INTRODUCTION}

This study was motivated by the recent interest in silver (Ag)-based inorganic semiconductors for photoelectrochemical (PEC) solar fuel generation and photocatalytic (PC) environmental remediation applications. Silver (I) oxide is a narrow bandgap $(1.2 \mathrm{eV})$ p-type semiconductor; ${ }^{1}$ however, its technological applicability is hindered by low PEC stability when exposed to light. ${ }^{2}$ On the other hand, compounds containing polyatomic anions based on $\mathrm{Ag}$, such as $\mathrm{Ag}_{3} \mathrm{PO}_{4}$, $\mathrm{Ag}_{3} \mathrm{VO}_{4}$ and $\mathrm{Ag}_{6} \mathrm{Si}_{2} \mathrm{O}_{7}$, show better stability under illumination while preserving optimal light absorption and electronic features such as good carrier transport and a Ag 4d-hybridized valence band stucture. $^{3-5}$

Bismuth and tungsten-based oxide semiconductors with the Aurivillius structure, of general formula $\left(\mathrm{Bi}_{2} \mathrm{O}_{2}\right)\left(\mathrm{A}_{\mathrm{m}-1} \mathrm{~B}_{\mathrm{m}} \mathrm{O}_{3 \mathrm{~m}+1}\right)$, are also of interest for the above applications. ${ }^{6}$ Thus $\mathrm{Bi}_{2} \mathrm{WO}_{6}$, an n-type semiconductor with an energy band gap, $\mathrm{E}_{\mathrm{g}}$ of $2.6 \mathrm{eV}$, exhibited PC activity for degradation of organic pollutants in water, such as rhodamine $\mathrm{B}$ dye and stearic acid. ${ }^{7,8}$ Further, it was reported that inducing oxygen vacancies at $\mathrm{Bi}_{2} \mathrm{WO}_{6}$ surface enhanced its photoactivity for 2,4-dichlorophenol oxidation. ${ }^{9}$ Interesting properties were reported for $\mathrm{Bi}_{2} \mathrm{WO}_{6}$ modified with Ag particles as well. ${ }^{10-12}$ The metallic domains not only acted as electron sinks suppressing electron-hole recombination, but also instigated surface plasmon resonance effects extending the light absorption to the visible range. ${ }^{13}$ Furthermore, the photoelectrode stability could be improved since charge accumulation in the crystal lattice was minimized. ${ }^{10-13}$ Hydrothermal synthesis (HTS) was reported as a practical one-step methodology for preparation of Ag-loaded $\mathrm{Bi}_{2} \mathrm{WO}_{6}$ composites from a mixture of $\mathrm{Bi}\left(\mathrm{NO}_{3}\right)_{3}, \mathrm{~K}_{2} \mathrm{WO}_{4}$ and $\mathrm{AgNO}_{3}$ precursors, followed by thermal treatment. ${ }^{11}$

In contrast to the rather extensive literature on $\mathrm{Bi}_{2} \mathrm{WO}_{6}$, corresponding studies on oxides combining all the three metallic elements above (for example, as in: $\mathrm{AgBiW}_{2} \mathrm{O}_{8}$ ) are scarce. Thus nanoparticles of $\mathrm{AgBiW}_{2} \mathrm{O}_{8}$ were prepared by solid-state reaction from a mixture of $\mathrm{Ag}_{2} \mathrm{O}, \mathrm{Bi}_{2} \mathrm{O}_{3}$ and $\mathrm{WO}_{3}{ }^{14}$ In aqueous suspension with methanol and $\mathrm{AgNO}_{3}$ as sacrificial reagents, $\mathrm{AgBiW}_{2} \mathrm{O}_{8}$ exhibited high activity toward both $\mathrm{H}_{2}$ and $\mathrm{O}_{2}$ evolution. ${ }^{14}$ Another subsequent study, by one of us, discussed the properties of $\mathrm{AgBiW}_{2} \mathrm{O}_{8}$ particles obtained by solution combustion synthesis (SCS) using $\mathrm{Na}_{2} \mathrm{WO}_{4}, \mathrm{AgNO}_{3}$ and $\mathrm{Bi}\left(\mathrm{NO}_{3}\right)_{3}$ solutions as precursors and urea as fuel. ${ }^{15}$ These $\mathrm{AgBiW}_{2} \mathrm{O}_{8}$ particles, with $\mathrm{E}_{\mathrm{g}}=2.74 \mathrm{eV}$, exhibited high $\mathrm{PC}$ activity for color removal of methyl orange dye aqueous solutions. Significantly, Pt-modified SCS-AgBiW ${ }_{2} \mathrm{O}_{8}$ particles were used for PEC generation of syngas from aqueous formic acid solution; the $\mathrm{CO}$ resulting from the 2ereduction of $\mathrm{CO}_{2}$ initially photogenerated on the oxide surface, while $\mathrm{H}_{2}$ was photogenerated on the Pt sites. ${ }^{15}$

This paper builds upon these findings and discusses the electrochemical and PEC properties of thin film electrodes of solution combustion synthesized oxides of Ag-Bi-W (hereafter designated: $\mathrm{SCS}-\mathrm{AgBiW}{ }_{2} \mathrm{O}_{8}$ and $\mathrm{SCS}_{-} \mathrm{Bi}_{2} \mathrm{WO}_{6}$ ). A novel tri-phasic powder consisting of $\mathrm{AgBiW}_{2} \mathrm{O}_{8}, \mathrm{Bi}_{2} \mathrm{WO}_{6}$ and $\mathrm{Ag}$ (hereafter designated: $\mathrm{HTS}-\mathrm{AgBiW} \mathrm{O}_{8} / \mathrm{Bi}_{2} \mathrm{WO}_{6} / \mathrm{Ag}$ ), was also prepared via hydrothermal synthesis from $\mathrm{Na}_{2} \mathrm{WO}_{4}, \mathrm{AgNO}_{3}$ and $\mathrm{Bi}\left(\mathrm{NO}_{3}\right)_{3}$ solutions as precursors. Two alternative routes were used to contrast a simple, fast way to obtain a singlephase photoactive material (SCS), with a more widely-deployed yet time-consuming method that, in the present case, afforded a multiphasic material with higher crystallinity (HTS). The Ag- 
Bi-W-based oxide behaved as a p-type semiconductor while $\mathrm{Bi}_{2} \mathrm{WO}_{6}$ nominally behaved as an $\mathrm{n}$ type semiconductor (as mentioned earlier). The structural, spectroscopic, and electrochemical/photoelectrochemical attributes of these samples, as established by a complementary suite of characterization techniques, are presented below. Finally, the applicability of these materials for solar fuels generation and environmental remediation scenarios, are also briefly discussed.

\section{EXPERIMENTAL METHODS}

All chemicals were of P.A. grade and used without further purification. Deionized water from a Milli-Q purification system was used throughout the work.

Synthesis of $\mathbf{S C S}-\mathbf{B i}_{2} \mathbf{W O}_{6}$ and $\mathbf{S C S}-\mathbf{A g B i W} \mathbf{O}_{\mathbf{8}}$. The $\mathrm{SCS}-\mathrm{AgBiW}_{2} \mathrm{O}_{8}$ synthesis was described elsewhere. ${ }^{15}$ Briefly, $\mathrm{AgNO}_{3}$ and $\mathrm{Bi}\left(\mathrm{NO}_{3}\right)_{3} .5 \mathrm{H}_{2} \mathrm{O}$ solutions were homogenized with $\mathrm{HNO}_{3}$ solution in a ceramic crucible and then an aqueous solution of $\mathrm{Na}_{2} \mathrm{WO}_{4}$ and urea was added (the $\mathrm{Ag}: \mathrm{Bi}: \mathrm{W}$ molar ratio corresponded to $1: 1: 2$ ). The resulting suspension was heated in a furnace and maintained at $190{ }^{\circ} \mathrm{C}$ for $3 \mathrm{~min}$. Finally, the produced particles were washed and dried. SCS$\mathrm{Bi}_{2} \mathrm{WO}_{6}$ particles were obtained from a similar procedure using bismuth and tungsten precursors with a Bi:W molar ratio of 2:1.

Synthesis and characterization of $\mathbf{H T S}-\mathbf{A g B i W} \mathbf{O}_{\mathbf{8}} / \mathbf{B i}_{2} \mathbf{W O}_{6} / \mathbf{A g}$. Firstly, $\mathrm{Bi}\left(\mathrm{NO}_{3}\right)_{3} .5 \mathrm{H}_{2} \mathrm{O}$ was dissolved in ethylene glycol and $\mathrm{HNO}_{3}$ aqueous solution; after water addition, the resulting 0.008 mol L-1 of $\mathrm{Bi}\left(\mathrm{NO}_{3}\right)_{3}$ solution was mixed to a $0.2 \mathrm{~mol} \mathrm{~L}^{-1}$ of $\mathrm{AgNO}_{3}$ solution (in aqueous $\mathrm{HNO}_{3}$ ). Then, under magnetic stirring, a $0.2 \mathrm{~mol} \mathrm{~L}^{-1}$ of $\mathrm{Na}_{2} \mathrm{WO}_{4}$ aqueous solution was slowly added, in adequate aliquots than the $\mathrm{Ag}: \mathrm{Bi}: \mathrm{W}$ molar ratio was 1:1:2. After that, the $\mathrm{pH}$ of the resulting suspension was adjusted to 4.0 by addition of finely divided solid $\mathrm{NaOH}$. The suspension was then transferred to a Teflon-lined stainless steel autoclave, sealed and maintained for $24 \mathrm{~h}$ at (190 $\pm 5){ }^{\circ} \mathrm{C}$. After cooling down at room temperature, the autoclave was opened and an aliquot of the supernatant was collected for analysis. The supernatant analysis revealed the presence of traces of $\mathrm{Ag}^{+}$ions (a white precipitate after $\mathrm{HCl}$ addition), whereas $\mathrm{Bi}^{3+}$ and $\mathrm{WO}_{4}^{2-}$ ions were not identified (in the presence of these ions, black particles of $\mathrm{BiI}_{3}$, or yellow particles of $\mathrm{H}_{2} \mathrm{WO}_{4}$ would precipitate after addition of $\mathrm{KI}$, or $\mathrm{HCl}$ solutions, respectively). ${ }^{16}$ The particles were washed with 5 cycles of agitation with water and centrifugation; from the second washing cycle on, $\mathrm{Ag}^{+}$ions were not detected in the supernatant.

The resulting dried particles $(1.0 \mathrm{~g})$ were crushed with acetylacetone $(30 \mu \mathrm{L})$ and then an aqueous solution of polyethylene glycol, PEG (MW 20000) was slowly added, resulting in a suspension with 10:30:60 mass \% of PEG:oxide: $\mathrm{H}_{2} \mathrm{O}$ which was submitted to magnetic stirring for $2 \mathrm{~h} .{ }^{17}$ This suspension was used for preparation of films or powdered samples. The thermal treatment was performed in air atmosphere by heating from ambient temperature to $350{ }^{\circ} \mathrm{C}(10$ ${ }^{\circ} \mathrm{C} \min ^{-1}$ ), maintained at $350{ }^{\circ} \mathrm{C}$ for $30 \mathrm{~min}$, and then heated and maintained for 30 min at $450{ }^{\circ} \mathrm{C}$.

Characterization of the $\mathrm{HTS}-\mathrm{AgBiW}{ }_{2} \mathrm{O}_{8} / \mathrm{Bi}_{2} \mathrm{WO}_{6} / \mathrm{Ag}$ powder included UV-visible diffuse reflectance spectroscopy (UV-Vis DRS), performed with a Teflon disc as the reference standard (Cary 5G Varian instrument, equipped with an integrating sphere). From $\mathrm{N}_{2}$ adsorption/desorption isotherms, determined at $77 \mathrm{~K}$, the specific surface area was determined using the Brunnauer-Emmet-Teller (BET) methodology; the measurements were taken on a Quantachrome equipment, after degassing of the particles at $120{ }^{\circ} \mathrm{C}$ for $15 \mathrm{~h}$. X-Ray diffraction 
(XRD) measurements were taken at ambient temperature using a RINT2000 Rigaku equipment with $\mathrm{Cu} \mathrm{K \alpha}(\lambda=1.5406 \AA)$ radiation, with $0.02^{\circ}$ step size and $10 \mathrm{~s}$ per point. The diffractograms of crystalline phases were compared with those of standards as reported in the International Centre for Diffraction Data (ICDD) database and in the Inorganic Crystal Structure Database (ICSD). Rietveld refinement was accomplished considering the contribution of monoclinic $\mathrm{AgBiW}_{2} \mathrm{O}_{8}$, orthorhombic $\mathrm{Bi}_{2} \mathrm{WO}_{6}$, cubic $\mathrm{Ag}$ and $\mathrm{Ag}_{2} \mathrm{WO}_{4}$. The fittings were evaluated in terms of the weighted and expected factors $\left(\mathrm{R}_{\mathrm{wp}}, \mathrm{R}_{\mathrm{ex}}\right)$, and their ratio, which corresponds to the goodness-of-fit $\left(\chi^{2}\right)$. High-resolution transmission electron microscopy (HR-TEM) images, with fast Fourier Transform (FFT) patterns, were obtained on a Hitachi H-9500 instrument, with samples supported on carbon (300-mesh) film. X-ray photoelectron spectroscopy (XPS) was performed on a Kratos Axis Ultra DLD instrument, equipped with Al-K $\alpha$ monochromatic source, charge neutralizer and hemispherical electron energy analyzer. Peak fitting was performed with XPSPeak 4.1 software, using binding energy values normalized to adventitious carbon (284.8 $\mathrm{eV}$ ). Photoluminescence (PL) spectroscopy measurements were carried out at ambient temperature on a time correlated single-photon counting (TCSPC) equipment from Edinburg Analytical Instruments, model FL 900 with a multichannel plate photomultiplier detector (Hamamatsu R3809-U-50). Excitation beam was generated by a pulsed diode laser operating at $\lambda_{\text {exc }}=375 \mathrm{~nm}$ (model PLED 370).

Preparation and characterization of electrodes of Ag-Bi-W oxides. Aqueous suspensions of SCS- $\mathrm{Bi}_{2} \mathrm{WO}_{6}$ and $\mathrm{SCS}-\mathrm{AgBiW} \mathrm{O}_{8}$ with 10:30:60 mass \% of PEG:oxide: $\mathrm{H}_{2} \mathrm{O}$ were prepared using the already described procedure. ${ }^{17}$ Transparent conductive glass-FTO pieces were used as substrate (TCO22-15, $15 \Omega /$ sq, Solaronix S.A, Switzerland) after a previous ultrasonic cleaning step in isopropyl alcohol. Electrodes were prepared by deposition of a thin film of the suspension on the substrate: adhesive tape was used to delimit a $1.0 \mathrm{~cm}^{2}$ area, where the oxide suspension was spread using a glass rod. After drying at room temperature, the tape was removed, and the electrode was subjected to thermal anneal (air atmosphere, $30 \mathrm{~min}$ at $350{ }^{\circ} \mathrm{C}$ and $30 \mathrm{~min}$ at 450 ${ }^{\circ} \mathrm{C}$ ). This procedure assures elimination of PEG and organic residues resulting in porous films with adhesion to different substrates. ${ }^{17}$ A dry oxide loading of $\sim 1.5 \mathrm{mg} \mathrm{cm}^{-2}$ was estimated on the substrate surface via this procedure.

The morphology of the Ag-Bi-W based oxide films deposited on glass-FTO was examined by scanning electron microscopy on a JEOL JSM 63601V instrument.

The electrochemical properties were investigated in a three-electrode cell assembled with quartz or with an optical glass window (ca. $90 \%$ transmittance for $\lambda>300 \mathrm{~nm}$ ). The working electrode, with geometrical area of $(1.0 \pm 0.1) \mathrm{cm}^{2}$, faced a Pt wire ring as a counterelectrode and the reference electrode, $\mathrm{Ag} / \mathrm{AgCl}$ (in aqueous $3 \mathrm{~mol} \mathrm{~L}^{-1}$ of $\mathrm{KCl}$ ) was placed inside in a Luggin capillary. The experiments were performed using ca. $10 \mathrm{~mL}$ of neutral aqueous solutions containing $\mathrm{KNO}_{3}, \mathrm{Na}_{2} \mathrm{SO}_{4}$ or $\mathrm{NaClO}_{4}$ in concentrations ranging from 0.05 to $0.5 \mathrm{~mol} \mathrm{~L}^{-1}$ as supporting electrolyte. PEC studies were carried out with supporting electrolyte solutions containing methyl viologen dichloride $\left(40 \mathrm{mmol} \mathrm{L}^{-1}\right)$ or $\mathrm{AgNO}_{3}\left(5 \mathrm{mmol} \mathrm{L}^{-1}\right)$ as electron acceptors. Prior to the measurements, the electrolyte was saturated with gaseous $\mathrm{N}_{2}$, argon, $\mathrm{O}_{2}$ or $\mathrm{CO}_{2}$ by flushing the gas through the solution for $30 \mathrm{~min}$; then, during the measurements, the same gas was maintained over the solution.

The electrochemical measurements were performed using either Solarton Instruments SI 1280 B or Ecochemie Autolab PGSTAT 302-N potentiostat/galvanostat units, in ambient illumination ("dark") and under front-side polychromatic irradiation. Irradiation was provided by a $1000 \mathrm{~W}$ 
Arc Xe lamp combined with an infrared filter, collimators and a monochromator (Oriel) for spectral resolution from 300 to $750 \mathrm{~nm}$. The irradiance was measured with Kettering or Newport power meters and was nominally $100 \mathrm{~mW} \mathrm{~cm}$.

Action spectra (or incident photon to current conversion efficiency (IPCE) vs. wavelength profiles) were acquired in aqueous solution with $0.1 \mathrm{~mol} \mathrm{~L}^{-1}$ of $\mathrm{KNO}_{3}$ and $5 \mathrm{mmol} \mathrm{L}{ }^{-1}$ of $\mathrm{AgNO}_{3}$. The electrode was polarized at $0.4 \mathrm{~V}$ (open-circuit potential in the dark) for this purpose, and the photocurrent was measured while the incident irradiation was scanned from 290 to $750 \mathrm{~nm}$ (intervals of $10 \mathrm{~nm}$, maintained for $50 \mathrm{~s})$. At every wavelength $(\lambda, \mathrm{nm})$, the IPCE value was estimated from the steady state photocurrent $\left(\mathrm{j}_{\mathrm{ph}}, \mathrm{mAcm}^{-2}\right)$ and the intensity of incident monochromatic irradiation $\left(\mathrm{I}_{\mathrm{in}}, \mathrm{mWcm}^{-2}\right)$, using the expression: IPCE $=\left(1240 \times \mathrm{j}_{\mathrm{ph}}\right) /\left(\lambda \times \mathrm{I}_{\mathrm{in}}\right)$.

\section{RESULTS AND DISCUSSION}

Characterization of Ag-Bi-W oxides. The structural characterization of the greyish SCS$\mathrm{AgBiW}_{2} \mathrm{O}_{8}$ nanoparticles obtained from solution combustion synthesis using urea as fuel and aqueous solutions of $\mathrm{Na}_{2} \mathrm{WO}_{4}, \mathrm{AgNO}_{3}$ and $\mathrm{Bi}\left(\mathrm{NO}_{3}\right)_{3}$ was already described. The sample consisted of crystalline $\mathrm{AgBiW}_{2} \mathrm{O}_{8}$ nanoparticles, with a BET surface area of $34 \mathrm{~m}^{2} \mathrm{~g}^{-1}$ and $\mathrm{E}_{\mathrm{g}}$ of $2.74 \mathrm{eV}$ (indirect transition). ${ }^{15}$

Adding ethylene glycol to these solutions, hydrothermal synthesis $\left(24 \mathrm{~h}\right.$ at $190{ }^{\circ} \mathrm{C}$, in autoclave) produced crystalline greyish nanoparticles consisting of $\mathrm{AgBiW}_{2} \mathrm{O}_{8}, \mathrm{Bi}_{2} \mathrm{WO}_{6}$ and $\mathrm{Ag}$; i.e., a triphasic sample, HTS-AgBiW ${ }_{2} \mathrm{O}_{8} / \mathrm{Bi}_{2} \mathrm{WO}_{6} / \mathrm{Ag}$. The BET surface area of the calcined sample was $42 \mathrm{~m}^{2} \mathrm{~g}^{-1}$. Figure 1 shows the XRD pattern exhibited by a calcined film of HTS$\mathrm{AgBiW} \mathrm{O}_{8} / \mathrm{Bi}_{2} \mathrm{WO}_{6} / \mathrm{Ag}$ nanoparticles deposited on glass. Comparison with the JCPDS database and using Rietveld refinement of X-Ray diffraction data (see Fig. S1), revealed that the sample prepared by HTS consisted of a mixture containing $35 \%$ of monoclinic $\mathrm{AgBiW}_{2} \mathrm{O}_{8}, 41 \%$ of orthorhombic $\mathrm{Bi}_{2} \mathrm{WO}_{6}$ and $20 \%$ of cubic $\mathrm{Ag}$, with $\mathrm{Ag}_{2} \mathrm{WO}_{4}(\sim 4 \%)$ adventiously arising as a decomposition product from the thermal anneal. Interestingly, ethylene glycol, added to facilitate dissolution of the Bi precursor, acted as a reducing agent and induced the production of metallic Ag domains. ${ }^{11}$

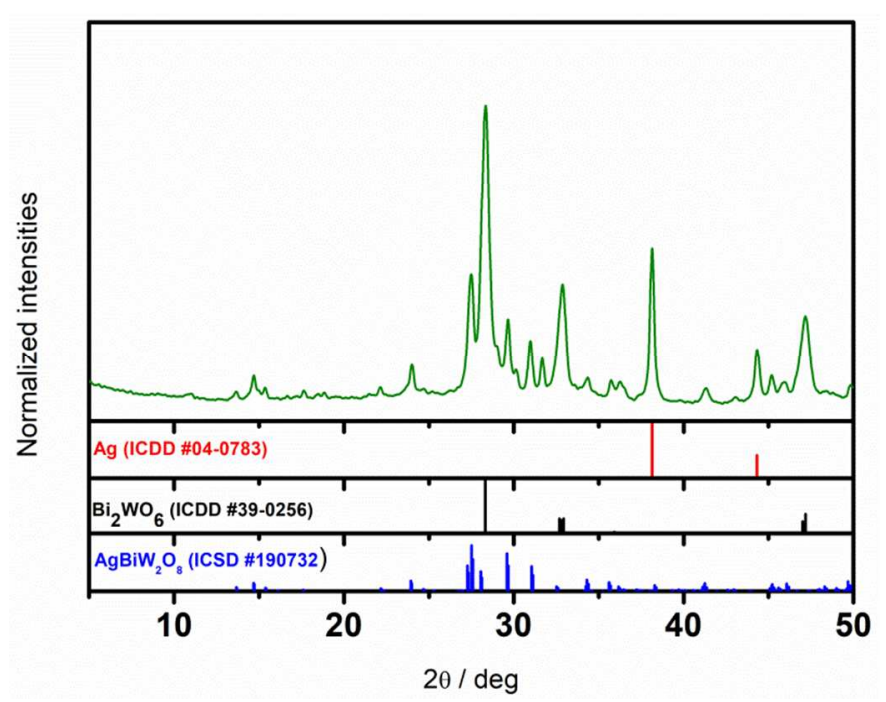


Figure 1. XRD pattern of HTS-AgBiW ${ }_{2} \mathrm{O}_{8} / \mathrm{Bi}_{2} \mathrm{WO}_{6} / \mathrm{Ag}$ film deposited on glass. The ICDD and ICSD reference patterns for $\mathrm{AgBiW}_{2} \mathrm{O}_{8}, \mathrm{Bi}_{2} \mathrm{WO}_{6}$, and $\mathrm{Ag}$ are also included.

Figure 2 shows the absorption spectrum (derived from UV-Vis DRS data) for the HTS$\mathrm{AgBiW}_{2} \mathrm{O}_{8} / \mathrm{Bi}_{2} \mathrm{WO}_{6} / \mathrm{Ag}$ powder. Considering the already reported optical characteristics of SCS$\mathrm{AgBiW}_{2} \mathrm{O}_{8},{ }^{15}$ it can be concluded that both materials present an absorption edge around $455 \mathrm{~nm}$, similar to the results previously reported in the literature for $\mathrm{AgBiW}_{2} \mathrm{O}_{8}{ }^{14}$ Thus, both SCS-

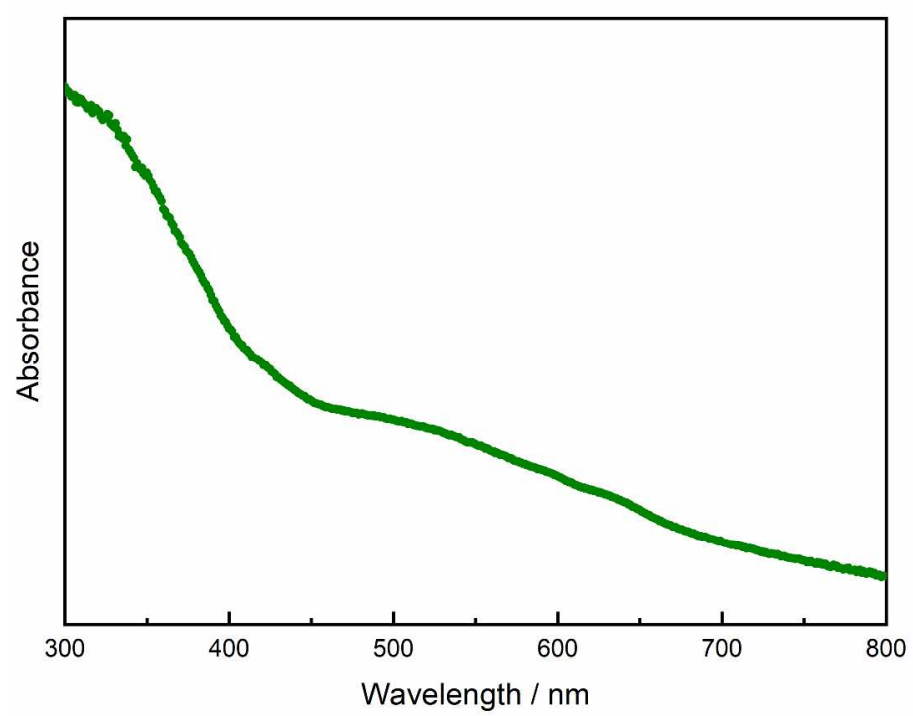

Figure 2. Absorption spectrum from UV-Vis DRS data for $\mathrm{HTS}-\mathrm{AgBiW} \mathrm{O}_{8} / \mathrm{Bi}_{2} \mathrm{WO}_{6} / \mathrm{Ag}$ nanoparticles.

$\mathrm{AgBiW}_{2} \mathrm{O}_{8}$ and $\mathrm{HTS}-\mathrm{AgBiW} \mathrm{O}_{8} / \mathrm{Bi}_{2} \mathrm{WO}_{6} / \mathrm{Ag}$ samples exhibited considerable absorption in the visible range of the solar spectrum. However, since the HTS- $\mathrm{AgBiW}_{2} \mathrm{O}_{8} / \mathrm{Bi}_{2} \mathrm{WO}_{6} / \mathrm{Ag}$ particles consisted of a mixture of $\mathrm{Ag}$ and two different complex oxides, estimation of $\mathrm{E}_{\mathrm{g}}$ from KubelkaMunk analyses ${ }^{18}$ was not attempted for the data in Fig. 2. Furthermore, the hydrothermally synthesized oxide exhibited an additional band at $\sim 500 \mathrm{~nm}$ (see Fig. 2), which can be assigned to surface plasmon resonance of metallic silver. ${ }^{12}$ These $\mathrm{Ag}^{0}$ domains serve additionally to extend the visible light absorption properties to the sample.

The HTS-AgBiW ${ }_{2} \mathrm{O}_{8} / \mathrm{Bi}_{2} \mathrm{WO}_{6} / \mathrm{Ag}$ sample was also analyzed by HR-TEM (Fig. 3). Figure $3 \mathrm{a}$ shows a TEM micrograph of this nanocomposite sample, which consisted of irregular shaped nanoparticles of $\mathrm{AgBiW}_{2} \mathrm{O}_{8}, \mathrm{Bi}_{2} \mathrm{WO}_{6}$ and $\mathrm{Ag}$, as revealed by the HRTEM image. The respective fast Fourier Transform (FFT) in Fig. 3b, showed epitaxial interface between the three phases. The lattice fringes indicated the interplanar distances to be $0.316 \mathrm{~nm}, 0.325 \mathrm{~nm}$ and $0.232 \mathrm{~nm}$, in good agreement with the spacing of the corresponding (131) plane of the orthorhombic $\mathrm{Bi}_{2} \mathrm{WO}_{6}$, (220) plane of the monoclinic $\mathrm{AgBiW}_{2} \mathrm{O}_{8}$ component, and the (111) plane of the face-centered cubic Ag nanoparticles, respectively. The obtained lattice spacings were also entirely consistent with the above XRD results. 

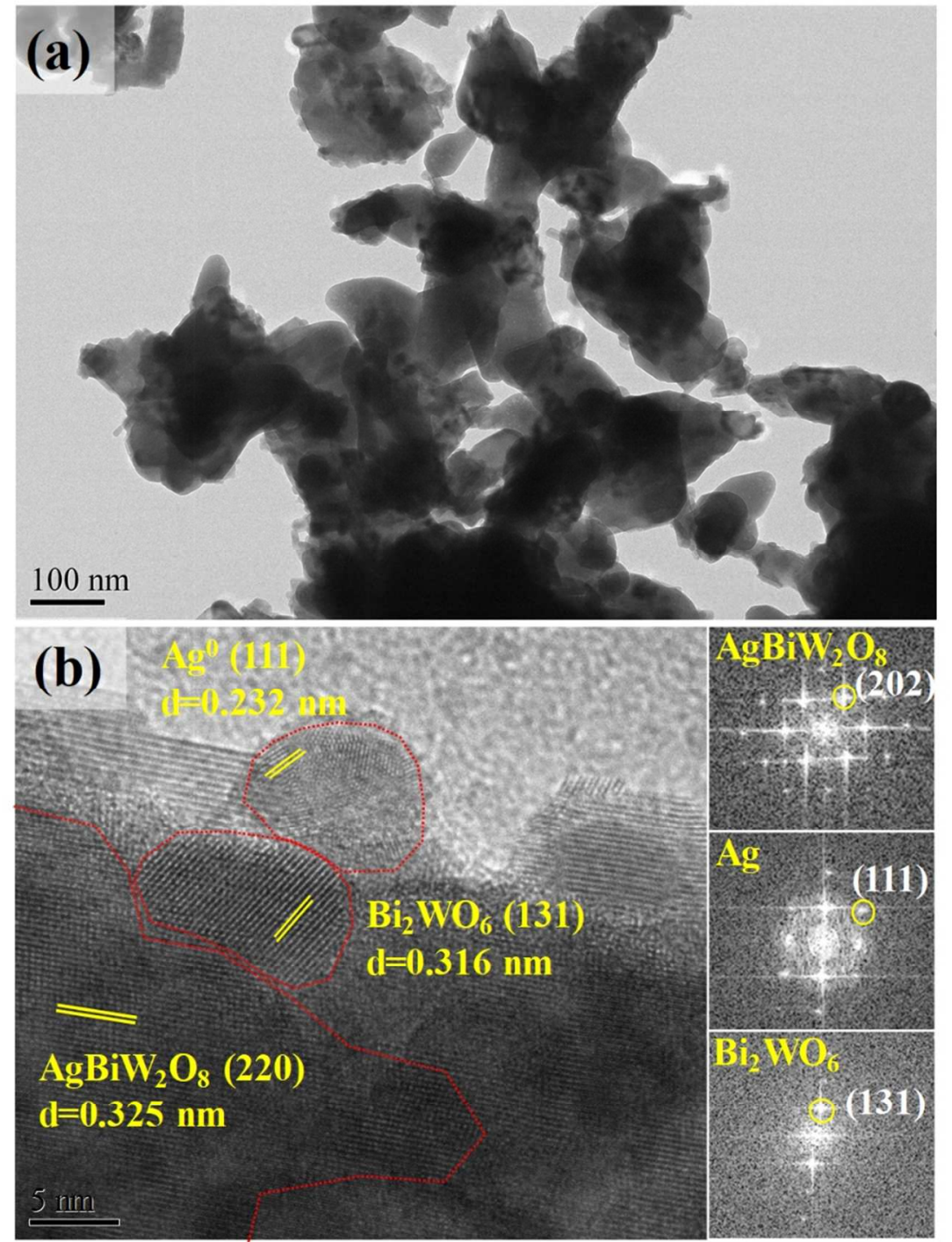

Figure 3. HTS-AgBiW ${ }_{2} \mathrm{O}_{8} / \mathrm{Bi}_{2} \mathrm{WO}_{6} / \mathrm{Ag}$ particles: TEM image (a) and HRTEM image with FFT patterns of each identified phase (b).

The same material was also subjected to XPS analyses (Fig. 4). Results obtained from powder samples indicate a defect-rich structure, with significant amount of atoms in less positive oxidation states than expected for a stoichiometric compound (binding energies and ratio of different oxidation states are shown in Table S1). The W 4 f core-level spectrum (Fig. 4a) showed $4 \mathrm{f}_{7 / 2}$ peaks at 35.6 and $36.8 \mathrm{eV}$ suggesting a significant presence of tungsten atoms at oxidation states lower than the expected $\mathrm{W}^{6+}$ species. ${ }^{19,20}$ This profile could indicate the existence of defects in the crystalline structure, such as oxygen vacancies and Frenkel defects, which would allow the presence of $\mathrm{W}^{5+}$ states. The $\mathrm{Ag} 3 \mathrm{~d}_{5 / 2}$ peaks around 368.0 and $369.0 \mathrm{eV}$ (Fig. 4b) confirmed the presence of metallic silver domains along with the expected $\mathrm{Ag}^{+} \mathrm{species}^{-}$ respectively. ${ }^{12,21}$ The curves obtained at the $\mathrm{Bi} 4 \mathrm{f}$ binding energy regime (Fig. $4 \mathrm{c}$ ), which consist of multiple overlapped peaks in the 157-160 eV range, indicated the presence of multiple oxidation states. As the expected oxidation state for bismuth was $3+$ in these compounds, and the synthetic medium provided a reductive environment, the existence of bismuth in the 5+ oxidation state could be ruled out. 
Although a small difference of $0.9 \mathrm{eV}$ could be expected for the binding energy of Bi $4 \mathrm{f}$ electrons in $\mathrm{Bi}_{2} \mathrm{WO}_{6}$ and $\mathrm{AgBiW}_{2} \mathrm{O}_{8}$, the two main overlapped signals (159.1 and $160.3 \mathrm{eV}$ ) may be attributed to bismuth atoms in the same oxidation state as in the case of $\mathrm{FeBiO}_{3}$ where $\mathrm{Bi}$-O$\mathrm{Bi}$ and $\mathrm{Fe}-\mathrm{O}-\mathrm{Bi}$ bonds provide distinct binding energies for $\mathrm{Bi}^{3+} \cdot{ }^{22}$ As the Aurivillius phase presents Bi-O-Bi layers in its structure, substitution of bismuth atoms by silver (possessing similar ionic radius) may be responsible for the observed shift in binding energy. Interestingly, the deconvolution of $\mathrm{Bi} 4 \mathrm{f}$ peaks also provided a small signal at even lower binding energy $(157.7 \mathrm{eV})$, hypothesized first to be $\mathrm{Bi}^{2+}$ cations and confirmed by photoluminescence experiments, discussed below. The O 1s spectrum (Fig. 4d) contained 3 peaks $(530.4,531.8$ and $533.9 \mathrm{eV}$ ), which can be ascribed to tungsten-oxygen bonds, ${ }^{20}$ surface hydroxyl groups ${ }^{23}$ (as expected for a defect-rich structure), and C-O bonds from adventitious hydrocarbons adsorbed on the oxide surface, ${ }^{24}$ respectively. Table S1 contains further (quantitative) details from the XPS analyses.
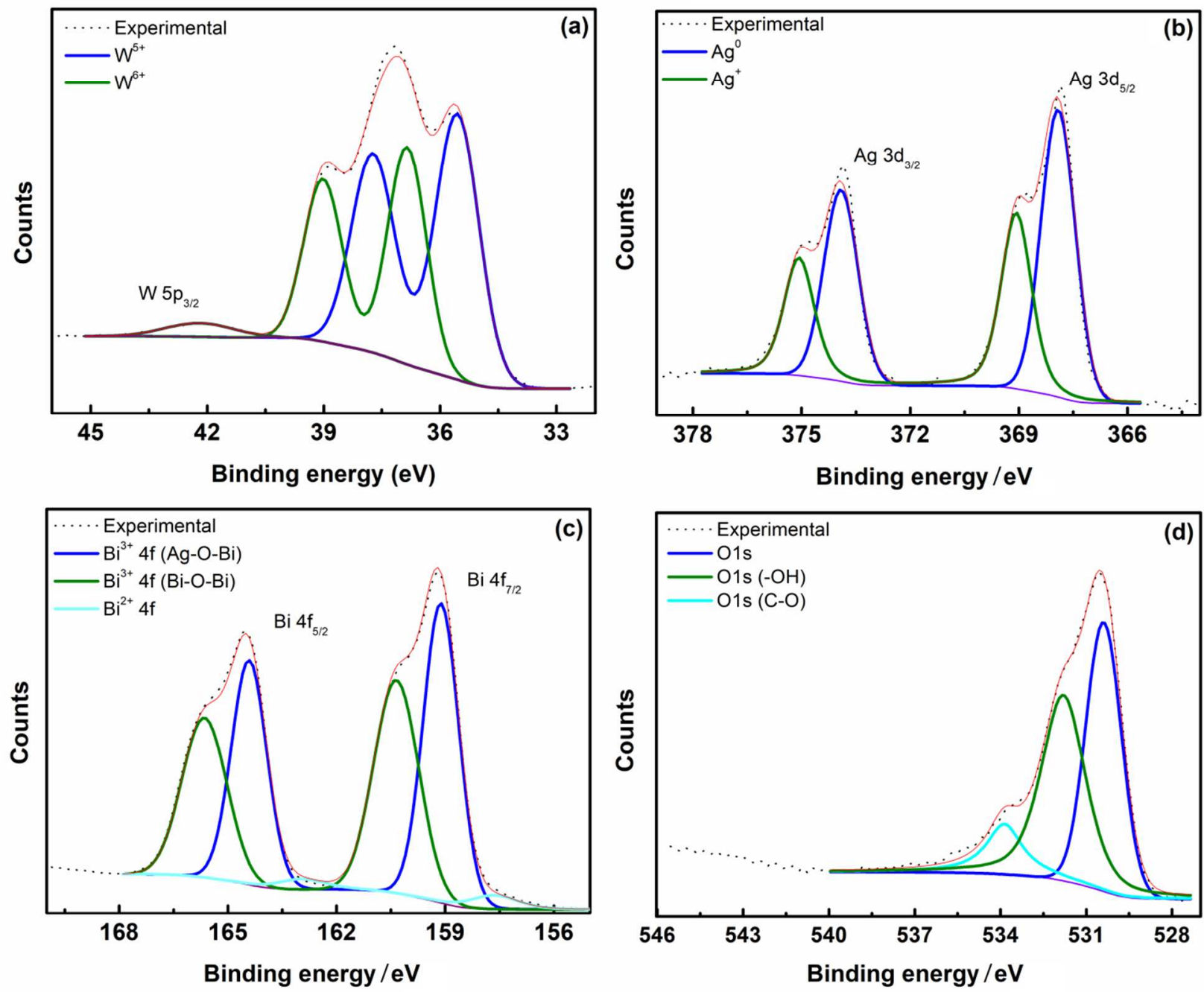

Figure 4. XPS analyses of HTS- $\mathrm{AgBiW}_{2} \mathrm{O}_{8} / \mathrm{Bi}_{2} \mathrm{WO}_{6} / \mathrm{Ag}$ in: (a) W 4f, (b) $\mathrm{Ag} 3 \mathrm{~d}$, (c) $\mathrm{Bi} 4 \mathrm{f}$ and (d) $\mathrm{O}$ 1s binding energy regimes (fitted profiles are shown as a red line). 
Photoemission spectroscopy measurements also provided further insights on the electronic structure of $\mathrm{HTS}-\mathrm{AgBiW}{ }_{2} \mathrm{O}_{8} / \mathrm{Bi}_{2} \mathrm{WO}_{6} / \mathrm{Ag}$; as shown in Fig. 5, the photoluminescence (PL) spectrum consisted of three (structured) emission bands ranging over the whole visible region. The broad band centered at $\sim 465 \mathrm{~nm}$ can be assigned to intrinsic emission from charge transfer transition between the conduction band (mainly composed of $\mathrm{W} 5 \mathrm{~d}$ orbitals) to the valence band, (composed of $\mathrm{Bi} 6 \mathrm{~s}$ and $\mathrm{O} 2 \mathrm{p}$ orbitals); see, for example, Refs. 25-27. The band centered at $\sim 535$ $\mathrm{nm}$ can be assigned to defect centers that may arise from the insertion of oxygen in interstitial positions with concomitant silver substitution (Frenkel-type defects). ${ }^{25}$ The third major band observed at longer wavelengths with peak at $\sim 620 \mathrm{~nm}$ is assigned to the intrinsic emission of $\mathrm{Bi}^{2+}$, as in the case of bismuth-activated $\mathrm{M}^{2+} \mathrm{BPO}_{5},{ }^{28}$ which corroborates with the hypothesis from XPS analyses (Fig. 4c above). The reduction of $\mathrm{Bi}^{3+}$ may be related to the use of ethylene glycol for the synthesis of HTS-AgBiW ${ }_{2} \mathrm{O}_{8} / \mathrm{Bi}_{2} \mathrm{WO}_{6} / \mathrm{Ag}$ (see above).

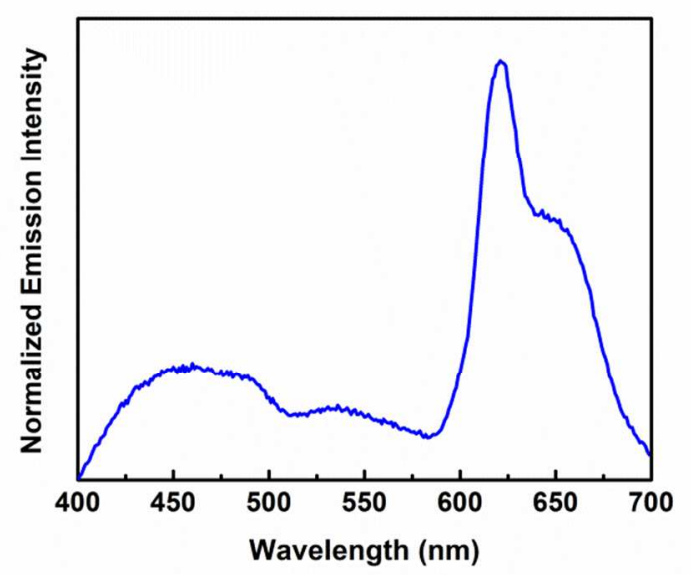

Figure 5. Photoluminescence spectrum of HTS-AgBiW $\mathrm{O}_{8} / \mathrm{Bi}_{2} \mathrm{WO}_{6} / \mathrm{Ag} . \lambda_{\text {exc }}=375 \mathrm{~nm}$.

Electrochemical and photoelectrochemical (PEC) properties of Ag-Bi-W oxide electrodes. Thin films of nanoparticles of the two Ag-Bi-W based oxides, with geometrical area of $1 \mathrm{~cm}^{2}$, were deposited on different substrates from aqueous suspensions containing PEG followed by thermal treatment. The average amount of immobilized particles on the substrates corresponded to $(1.5 \pm 0.2) \mathrm{mg} \mathrm{cm}$; usually, deposition of $\mathrm{TiO}_{2}$ particles on glass-FTO using this methodology corresponded to smaller values, $(1.2 \pm 0.2) \mathrm{mg} \mathrm{cm}^{-2} \cdot{ }^{17}$ Representative SEM images for these films are shown in Fig. S2. Comparison of these images revealed similar morphology; films of both these materials, consisted of interconnected sub-micrometric agglomerates of nanosized primary particles.

The electrochemical properties of the electrodes were investigated in supporting electrolyte aqueous solutions (neutral $\mathrm{pH}$ ) by cyclic voltammetry. In such media and under ambient illumination (i.e., "dark"), the rest potential $\left(\mathrm{V}_{\text {rest }}\right)$ varied from 0.1 to $0.2 \mathrm{~V}$ (vs. $\mathrm{Ag} / \mathrm{AgCl}$ ). In aqueous $\mathrm{NaClO}_{4}$ solution, when the applied potential was scanned from $\mathrm{V}_{\text {rest }}$ to $-0.3 \mathrm{~V}$, the electrodes exhibited stable and reproducible current-potential profiles and, for potential values $\mathrm{E}_{\mathrm{V}}<\mathrm{V}_{\text {rest }}$, the cathodic current was intensified by irradiation, as will be discussed below. 
However, as can be observed in Fig. 6a, for potentials $\mathrm{E}_{\mathrm{V}}>\mathrm{V}_{\text {rest }}$, the voltammograms of a SCS$\mathrm{AgBiW}_{2} \mathrm{O}_{8}$ electrode exhibited an anodic peak at ca. $0.4 \mathrm{~V}$ and, for the reverse sweep, a cathodic peak at $\sim 0.2 \mathrm{~V}$; also, the waves decreased in amplitude with potential cycling. Analogous results were obtained for the HTS- $\mathrm{AgBiW}_{2} \mathrm{O}_{8} / \mathrm{Bi}_{2} \mathrm{WO}_{6} / \mathrm{Ag}$ electrode (Fig. 6b); however, the anodic and cathodic current peaks were respectively observed at $\sim 0.2 \mathrm{~V}$ and $\sim 0.1 \mathrm{~V}$ instead.

These features can be assigned to redox process within silver oxides, as well as intercalated silver species ${ }^{29,30}$ that may be present at the layered $\mathrm{AgBiW}_{2} \mathrm{O}_{8}$ structure. Also, the peaks were sharper in the $\mathrm{HTS}-\mathrm{AgBiW} \mathrm{O}_{8} / \mathrm{Bi}_{2} \mathrm{WO}_{6} / \mathrm{Ag}$ case, indicating faster kinetics for this internal process when compared to the $\mathrm{SCS}-\mathrm{AgBiW}_{2} \mathrm{O}_{8}$ electrode. These could be attributed to the $\mathrm{Ag}$ metallic domains and to the higher tunneling current, as a consequence of a lower energy barrier height ${ }^{30}$ (as expected from the presence of $\mathrm{Bi}_{2} \mathrm{WO}_{6}$, which presents a lower conduction band minimum than $\mathrm{AgBiW}_{2} \mathrm{O}_{8}$ ). The alternate possibility that these redox signatures arise from
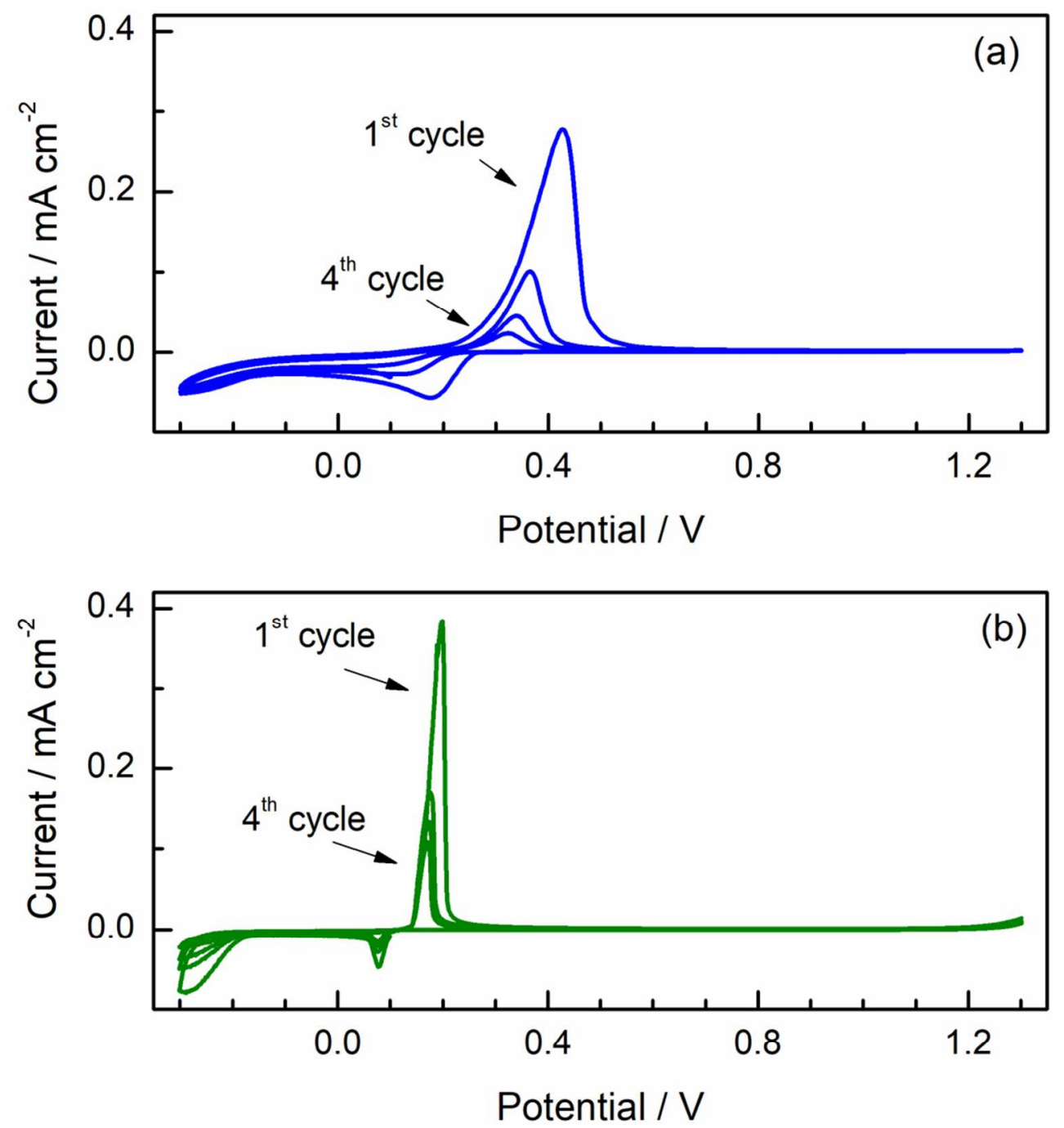

Figure 6. The four initial cyclic voltammograms $\left(20 \mathrm{mVs}^{-1}\right)$ of $\mathrm{SCS}_{-} \mathrm{AgBiW}_{2} \mathrm{O}_{8}$ (a) and HTS$\mathrm{AgBiW} \mathrm{O}_{8} / \mathrm{Bi}_{2} \mathrm{WO}_{6} / \mathrm{Ag}$ (b) porous films $\left(1 \mathrm{~cm}^{2}\right)$ deposited on glass-FTO in aqueous $\mathrm{NaClO}_{4}$ solution, in ambient illumination ("dark"). Pt wire and $\mathrm{Ag} / \mathrm{AgCl} / \mathrm{KCl}$ (saturated) were used as counter and reference electrodes, respectively. 
metallic Ag domains can be ruled out since these are present for both the SCS and HTS samples (c.f., Figs. 6a and b)

To further compare the Ag-Bi-W based oxides against the Ag-deficient counterpart, namely, $\mathrm{Bi}_{2} \mathrm{WO}_{6}$, experiments were performed using aqueous solutions containing dissolved $\mathrm{O}_{2}$, methylviologen dichloride or silver (I) ions as electron acceptors. Figure 7a shows the voltammograms registered in $\mathrm{O}_{2}$-saturated $\mathrm{NaClO}_{4}$ aqueous solution $\left(20 \mathrm{mVs}^{-1}\right)$. From 0.1 to $-0.3 \mathrm{~V}$, the $\mathrm{Bi}_{2} \mathrm{WO}_{6}$ electrode exhibited identical voltammograms and negligible current flow in the dark and under irradiation. On the other hand, the cathodic current exhibited by the SCS$\mathrm{AgBiW}_{2} \mathrm{O}_{8}$ electrode in the dark indicates its high proclivity towards the oxygen reduction reaction. This trend is also corroborated by comparing the cyclic voltammograms obtained in $\mathrm{N}_{2}$ - and $\mathrm{O}_{2}$-saturated solutions (Fig. S3).
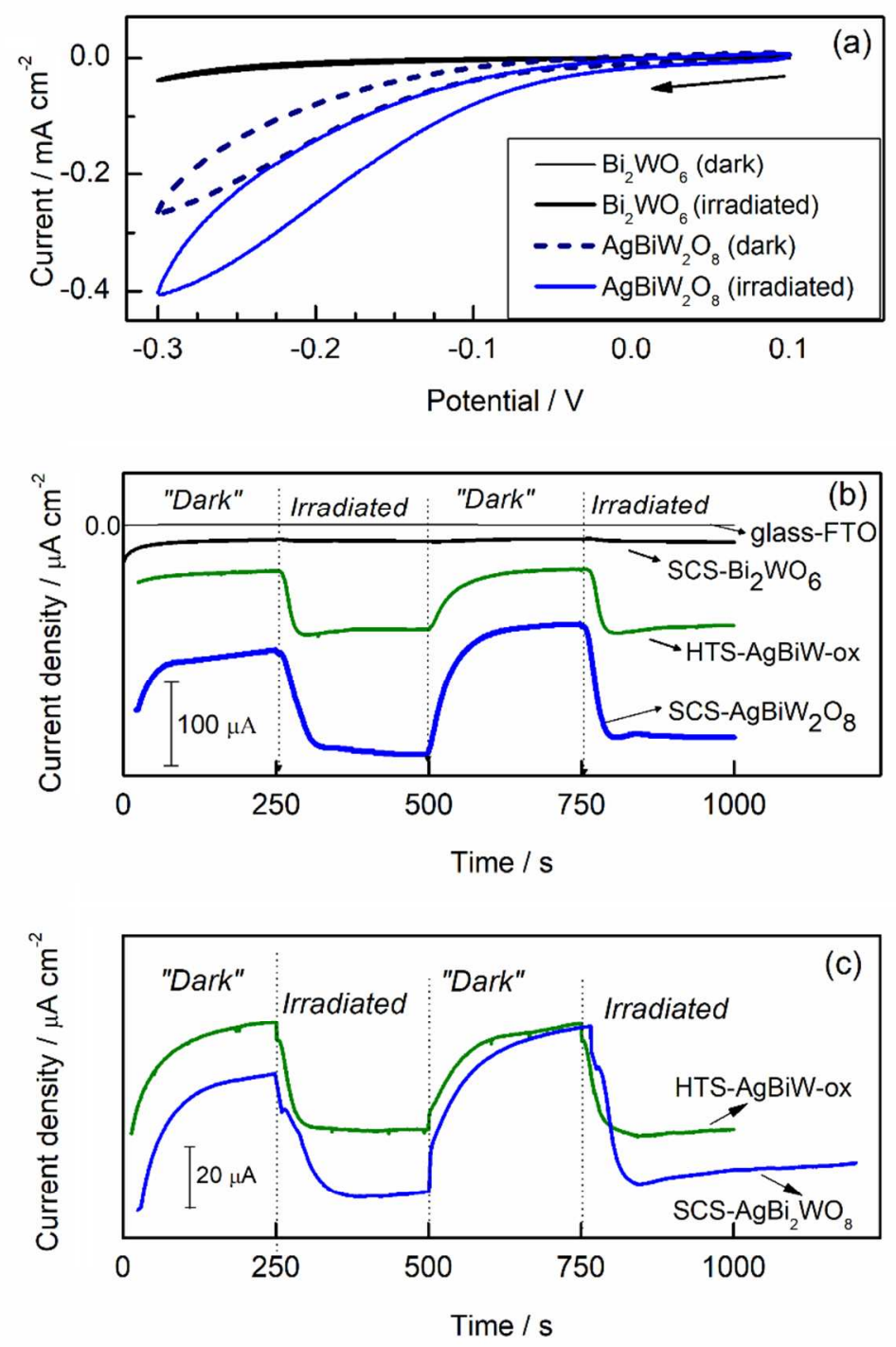

Figure 7. Electrochemical and PEC behavior of SCS- $\mathrm{Bi}_{2} \mathrm{WO}_{6}, \mathrm{SCS}-\mathrm{AgBiW} \mathrm{O}_{8}$, and $\mathrm{HTS}-\mathrm{AgBiW} \mathrm{O}_{8} / \mathrm{Bi}_{2} \mathrm{WO}_{6} / \mathrm{Ag}$ in aqueous solutions containing electron acceptor species, in the dark or under irradiation: cyclic voltammograms $(20$ $\mathrm{mVs}^{-1}$ ) in $\mathrm{O}_{2}$ saturated $\mathrm{NaClO}_{4}$ solution (a) and photocurrent transients at $-0.3 \mathrm{~V}$ ( $\mathrm{vs}$. $\mathrm{Ag} / \mathrm{AgCl}$ ) in $\mathrm{O}_{2}$ saturated $\mathrm{NaClO}_{4}$ solution (b) or in $\mathrm{Na}_{2} \mathrm{SO}_{4}$ solution with methylviologen dichloride (c). Data taken for the substrate glass- 
FTO also included for comparison in Fig. 7b. In Figs. $7 b$ and c, the black, green, and blue traces have been off-set (from the zero current point) for clarity.

The cathodic current was intensified by irradiation, suggesting that $\mathrm{SCS}-\mathrm{AgBiW}{ }_{2} \mathrm{O}_{8}$ behaves as a p-type semiconductor electrode for $E_{\text {bias }}<V_{\text {rest. }}{ }^{31}$ Cathodic photocurrents could also be observed in the chronoamperograms obtained for electrodes of $\mathrm{Ag}-\mathrm{Bi}-\mathrm{W}$ based oxides under intermittent irradiation and polarization at $-0.3 \mathrm{~V}$ in $\mathrm{O}_{2}$ saturated $\mathrm{NaClO}_{4}$ aqueous solution (Fig. $7 b$ ) as well as in $\mathrm{Na}_{2} \mathrm{SO}_{4}$ aqueous solution containing methyl viologen dichloride (Fig. 7c). As expected and as a control, the PEC properties of the underlying glass-FTO substrate were negligible (see, for example, Fig. 7b) under these conditions.

The photoelectrochemical properties of $\mathrm{Bi}_{2} \mathrm{WO}_{6}$ electrodes were already reported. ${ }^{32,33}$ Depending on the film thickness and porosity, under polychromatic irradiation in aqueous $\mathrm{Na}_{2} \mathrm{SO}_{4}$ solution, $\mathrm{Bi}_{2} \mathrm{WO}_{6}$ electrodes exhibited anodic photocurrent ranging from 1 to $20 \mu \mathrm{Acm}^{-2}$ in potentiodynamic scans from 0 to $1.0 \mathrm{~V}$ (vs $\mathrm{SCE}$ ). For monochromatic irradiation, the $\mathrm{Bi}_{2} \mathrm{WO}_{6}$ electrodes exhibited photoactivity for wavelengths up to $450 \mathrm{~nm}$, with the highest photocurrent values for incident photons with ca. $340 \mathrm{~nm}$ (1.2\% IPCE). Thus, electrodes of this n-type semiconductor have been used as photoanodes for photocatalytic oxidation of organic pollutants in aqueous media.

However, upon a detailed review of the literature, we believe that this is the first description of the electrochemical properties of $\mathrm{AgBiW}_{2} \mathrm{O}_{8}$ electrodes. The p-type behavior, resulting from an increased mobility of positive charge carriers in the semiconductor, can be associated with metal ion vacancies or oxygen excess. ${ }^{34,35}$ The VB could also be modulated by Ag 4d states, considering the reported band structure and partial density-of-states calculated by density functional theory. ${ }^{15}$ From calculations based on a wolframite $\mathrm{AgBiW}_{2} \mathrm{O}_{8}$ lattice (considered the most stable among other possible monoclinic structures), it was proposed that the conduction band minimum could be associated with $\mathrm{W} 5 \mathrm{~d}$ and the Bi $6 \mathrm{p}$ levels. ${ }^{15}$ Also, the upper part of the wolframite $\mathrm{AgBiW}_{2} \mathrm{O}_{8} \mathrm{VB}$ would be dominated by $\mathrm{Ag} 4 \mathrm{~d}$ contribution, while the $\mathrm{O} 2 \mathrm{p}$ contribution for the top of VB would not be significant. ${ }^{15}$ Thus, the VB modulation by Ag $4 \mathrm{~d}$ states could increase the hole mobility for irradiated $\mathrm{AgBiW}_{2} \mathrm{O}_{8}$ electrodes under cathodic polarization; these holes would move toward the bulk to reach the external circuit while photoelectrons would be driven to the electrode surface and react with electron acceptors such as $\mathrm{O}_{2}$, methylviologen or silver (I) ions.

Since these Ag-Bi-W-based oxides behaved as p-type semiconductor electrodes under cathodic polarization, they could be used as photocathodes for $\mathrm{O}_{2}$ reduction (ORR) and for the $\mathrm{CO}_{2}$ reduction reaction $\left(\mathrm{CO}_{2} \mathrm{RR}\right)$. Thus, in preliminary experiments, band gap irradiation improved the production of formate from $\mathrm{CO}_{2} \mathrm{RR}$ using $\mathrm{HTS}-\mathrm{AgBiW} \mathrm{O}_{8} / \mathrm{Bi}_{2} \mathrm{WO}_{6} / \mathrm{Ag}$ as photocathode in $\mathrm{CO}_{2}$-saturated acetonitrile containing trihexyltetra-decylphosphonium 1,2,4-triazolide, $\left[\mathrm{P}_{6,6,6,14}\right][1,2,4-$ Triz $]$ (a superbasic ionic liquid that interacts with $\mathrm{CO}_{2}$ ). ${ }^{36},{ }^{37}$ Further, for a photocatalytic system consisted of a $\mathrm{TiO}_{2}$ photoanode and a $\mathrm{HTS}-\mathrm{AgBiW}{ }_{2} \mathrm{O}_{8} / \mathrm{Bi}_{2} \mathrm{WO}_{6} / \mathrm{Ag}$ photocathode, preliminary results revealed that the hydrogen peroxide produced from light assisted ORR enhanced the efficiency for photocatalytic removal of the amoxycillin antibiotic from aqueous solution. Clearly, these p-type Ag-Bi-W-based oxides can be considered as promising photocathodes for solar fuels generation and environmental remediation scenarios. 


\section{Conclusions}

Complex oxides derived from $\mathrm{Ag}, \mathrm{Bi}$, and $\mathrm{W}$ were derived by two variant preparation approaches. While solution combustion synthesis (SCS) afforded nanoparticle powders of $\mathrm{AgBiW}_{2} \mathrm{O}_{8}$ and $\mathrm{Bi}_{2} \mathrm{WO}_{6}$, the hydrothermal synthesis (HTS) procedure, yielded, interestingly enough, a tri-phasic material composed of $\mathrm{AgBiW}_{2} \mathrm{O}_{8}, \mathrm{Bi}_{2} \mathrm{WO}_{6}$, and $\mathrm{Ag}$ nanoparticles. That these nanoparticles were in electronic contact was well substantiated by the variety of characterization probes deployed in this study. The presence of embedded Ag nanoparticles in the sample matrix had a positive optoelectronic effect stemming from surface plasmon resonance. While it is tempting to speculate that $\mathrm{p}$ - $\mathrm{n}$ semiconductor nano-junctions were also present in the matrix because $\mathrm{AgBiW}_{2} \mathrm{O}_{8}$ behaved as a p-type semiconductor (as established in this study) and $\mathrm{Bi}_{2} \mathrm{WO}_{6}$ is an n-type semiconductor, further studies would be needed, beyond the scope of this study, to address this possibility. The high defect density in the $\mathrm{HTS}-\mathrm{AgBiW}{ }_{2} \mathrm{O}_{8} / \mathrm{Bi}_{2} \mathrm{WO}_{6} / \mathrm{Ag}$ samples (as shown by the XPS and PL data), also calls for further optimization efforts before practical applications of these oxides for solar fuel generation are considered. Finally, further studies addressing the PEC stability of the oxides generated in this study, would be needed.

\section{SUPPORTING INFORMATION}

Rietveld refinement of XRD data for HTS-AgBiW $\mathrm{O}_{8} / \mathrm{Bi}_{2} \mathrm{WO}_{6} / \mathrm{Ag}$, XPS peak deconvolution, SEM data, and additional electrochemical measurements,

\section{ACKNOWLEDGMENTS}

This work was supported, in part, by CNPq, FAPESP, National Institute of Science, Technology and Innovation on Advanced Complex Materials (INOMAT), and by the University of Texas at Arlington. C. Longo and M. T. Galante gratefully acknowledge CAPES-PDSE program for financial support (process number 88881.131530/2016-01), Fulbright, and Royal Society of Chemistry for scholarships. Dr. Teresa Atvars (UNICAMP) provided the photoluminescence spectroscopy instrument set-up. Finally, we thank the two anonymous reviewers for their insightful comments and constructive criticisms. 


\section{References}

(1) Wu, M.; Yan, J.-M.; Zhang, X.-W.; Zhao, M.; Jiang, Q. $\mathrm{Ag}_{2} \mathrm{O}$ Modified G-C $\mathrm{N}_{4}$ for Highly Efficient Photocatalytic Hydrogen Generation under Visible Light Irradiation. $J$. Mater. Chem. A 2015, 358, 15710-15714.

(2) Wang, X.; Li, S.; Yu, H.; Yu, J.; Liu, S. $\mathrm{Ag}_{2} \mathrm{O}$ as a New Visible-Light Photocatalyst: SelfStability and High Photocatalytic Activity. Chem. - A Eur. J. 2011, 17 (28), 7777-7780.

(3) Bi, Y.; Ouyang, S.; Umezawa, N.; Cao, J.; Ye, J. Facet Effect of Single-Crystalline $\mathrm{Ag}_{3} \mathrm{PO}_{4}$ Sub-Microcrystals on Photocatalytic Properties. J. Am. Chem. Soc. 2011, 133 (17), 6490-6492.

(4) Konta, R.; Kato, H.; Kobayashi, H.; Kudo, A. Photophysical Properties and Photocatalytic Activities under Visible Light Irradiation of Silver Vanadates. Phys. Chem. Chem. Phys. 2003, 5 (14), 3061.

(5) Lou, Z.; Qin, X.; Dai, Y.; Whangbo, M. $\mathrm{Ag}_{6} \mathrm{Si}_{2} \mathrm{O}_{7}$ : A Silicate Photocatalyst for the Visible Region. Chem. Mater. 2014, 26, 3873-3875.

(6) Janáky, C.; Rajeshwar, K.; De Tacconi, N. R.; Chanmanee, W.; Huda, M. N. TungstenBased Oxide Semiconductors for Solar Hydrogen Generation. Catal. Today 2013, 199 (1), 53-64.

(7) He, D.; Wang, L.; Xu, D.; Zhai, J.; Wang, D.; Xie, T. Investigation of Photocatalytic Activities over $\mathrm{Bi}_{2} \mathrm{WO}_{6} / \mathrm{ZnWO}_{4}$ Composite under UV Light and Its Photoinduced Charge Transfer Properties. ACS Appl. Mater. Interfaces 2011, 3 (8), 3167-3171.

(8) Saison, T.; Gras, P.; Chemin, N.; Chane, C.; Durupthy, O.; Brezova, V.; Colbeau-justin, C.; Jolivet, J. New Insights into $\mathrm{Bi}_{2} \mathrm{WO}_{6}$ Properties as a Visible-Light Photocatalyst. $J$. Phys. Chem. C 2013, 117, 22656-22666.

(9) Lv, Y.; Yao, W.; Zong, R.; Zhu, Y. Fabrication of Wide - Range - Visible Photocatalyst $\mathrm{Bi}_{2} \mathrm{WO}_{6-\mathrm{x}}$ Nanoplates via Surface Oxygen Vacancies. Sci. Rep. 2016, 6, 19347.

(10) Zhang, Z.; Wang, W.; Gao, E.; Sun, S.; Zhang, L. Photocatalysis Coupled with Thermal Effect Induced by SPR on Ag-Loaded $\mathrm{Bi}_{2} \mathrm{WO}_{6}$ with Enhanced Photocatalytic Activity. $J$. Phys. Chem. C 2012, 116 (49), 25898-25903.

(11) Zhou, Y.; Zhang, Q.; Lin, Y.; Antonova, E.; Bensch, W.; Patzke, G. R. One-Step Hydrothermal Synthesis of Hierarchical $\mathrm{Ag} / \mathrm{Bi}_{2} \mathrm{WO}_{6}$ Composites: In Situ Growth Monitoring and Photocatalytic Activity Studies. Sci. China Chem. 2013, 56 (4), 435-442.

(12) Wang, D.; Xue, G.; Zhen, Y.; Fu, F.; Li, D. Monodispersed Ag Nanoparticles Loaded on the Surface of Spherical $\mathrm{Bi}_{2} \mathrm{WO}_{6}$ Nanoarchitectures with Enhanced Photocatalytic Activities. J. Mater. Chem. 2012, 22, 4751.

(13) Tang, J.; Ye, J. Correlation of Crystal Structures and Electronic Structures and Photocatalytic Properties of the W-Containing Oxides. J. Mater. Chem. 2005, 15, 42464251 .

(14) de Tacconi, N. R.; Timmaji, H. K.; Chanmanee, W.; Huda, M. N.; Sarker, P.; Janáky, C.; Rajeshwar, K. Photocatalytic Generation of Syngas Using Combustion-Synthesized Silver Bismuth Tungstate. ChemPhysChem 2012, 13 (12), 2945-2955. 
(15) Vogel, A. I. Textbook of Macro and Semimicro Qualitative Inorganic Analysis, 5th ed.; Longman, 1979.

(16) Oliveira, H. G.; Ferreira, L. H.; Bertazzoli, R.; Longo, C. Remediation of 17- a Ethinylestradiol Aqueous Solution by Photocatalysis and Electrochemically- Assisted Photocatalysis Using $\mathrm{TiO}_{2}$ and $\mathrm{TiO}_{2} / \mathrm{WO}_{3}$ Electrodes Irradiated by a Solar Simulator. Water Res. 2014, 72, 305-314.

(17) Habisreutinger, S. N.; Schmidt-Mende, L.; Stolarczyk, J. K. Photocatalytic Reduction of $\mathrm{CO}_{2}$ on $\mathrm{TiO}_{2}$ and Other Semiconductors. Angew. Chemie - Int. Ed. 2013, 52 (29), 73727408 .

(18) Murphy, A. B. Band-gap determination from diffuse reflectance measurements of semiconductor films, and application for photoelectrochemical water splitting. Sol. Energy Mater. Sol. Cells 2007, 91, 1326-1337.

(19) Haber, J.; Stoch, J.; Ungier, L. Electron Spectroscopic Studies of the Reduction of $\mathrm{WO}_{3} . J$. Solid State Chem. 1976, 19 (2), 113-115.

(20) Pomp, S.; Kuhness, D.; Barcaro, G.; Sementa, L.; Mankad, V.; Fortunelli, A.; Sterrer, M.; Netzer, F. P.; Surnev, S. Two-Dimensional Iron Tungstate: A Ternary Oxide Layer with Honeycomb Geometry. J. Phys. Chem. C 2016, 120 (14), 7629-7638.

(21) Ferraria, A. M.; Carapeto, A. P.; Botelho Do Rego, A. M. X-Ray Photoelectron Spectroscopy: Silver Salts Revisited. Vacuum 2012, 86 (12), 1988-1991.

(22) Aslam, M.; Soomro, M. T.; Ismail, I. M. I.; Qari, H. A.; Gondal, M. A.; Hameed, A. The Facile Synthesis, Characterization and Evaluation of Photocatalytic Activity of Bimetallic $\mathrm{FeBiO}_{3}$ in Natural Sunlight Exposure. RSC Adv. 2015, 5 (124), 102663-102673.

(23) Rettie, A. J. E.; Klavetter, K. C.; Lin, J. F.; Dolocan, A.; Celio, H.; Ishiekwene, A.; Bolton, H. L.; Pearson, K. N.; Hahn, N. T.; Mullins, C. B. Improved Visible Light Harvesting of $\mathrm{WO}_{3}$ by Incorporation of Sulfur or Iodine: A Tale of Two Impurities. Chem. Mater. 2014, 26 (4), 1670-1677.

(24) Jackman, M. J.; Thomas, A. G.; Muryn, C. Photoelectron Spectroscopy Study of Stoichiometric and Reduced Anatase $\mathrm{TiO}_{2}$ (101) Surfaces: The Effect of Subsurface Defects on Water Adsorption at near-Ambient Pressures. J. Phys. Chem. C 2015, 119 (24), 13682-13690.

(25) Bhoi, Y. P.; Pradhan, S. R.; Behera, C.; Mishra, B. G. Visible Light Driven Efficient Photocatalytic Degradation of Congo Red Dye Catalyzed by $\mathrm{CuS}-\mathrm{Bi}_{2} \mathrm{Cu}_{\mathrm{x}} \mathrm{W}_{1-\mathrm{x}} \mathrm{O}_{6-2 \mathrm{x}} \cdot R S C$ Adv. 2016, 6, 35589-35601.

(26) Li, J.; Guo, Z.; Zhu, Z. Ag/ $\mathrm{Bi}_{2} \mathrm{WO}_{6}$ Plasmonic Composites with Enhanced Visible Photocatalytic Activity. Ceram. Int. 2014, 40 (5), 6495-6501.

(27) Xiao, Q.; Zhang, J.; Xiao, C.; Tan, X. Photocatalytic Degradation of Methylene Blue over $\mathrm{Co}_{3} \mathrm{O}_{4} / \mathrm{Bi}_{2} \mathrm{WO}_{6}$ Composite under Visible Light Irradiation. Catal. Commun. 2008, 9 (6), 1247-1253.

(28) Srivastava, A. M. Luminescence of Divalent Bismuth in $\mathrm{MBPO}_{5}(\mathrm{M}=\mathrm{Ba}, \mathrm{Sr}$ and $\mathrm{Ca}) . J$. Lumin. 1998, 78, 239-243. 
(29) Mojovic, Z.; Milutinovic-Nikolic, A.; Bankovic, P.; Mentus, S.; Jovanovic, D. Electrochemical Behavior of Silver-Impregnated Al-Pillared Smectite in Alkaline Solution. J. Solid State Electrochem. 2010, 14 (9), 1621-1627.

(30) Unal, U.; Ida, S.; Shimogawa, K.; Altuntasoglu, O.; Izawa, K.; Ogata, C.; Inoue, T.; Matsumoto, Y. Electrochemical Behavior of $\mathrm{Ag}^{+}$Intercalated Layered Oxides. $J$. Electroanal. Chem. 2006, 595 (2), 95-102.

(31) Rajeshwar, K. Fundamentals of Semiconductor Electrochemistry and Photoelectrochemistry. Encyclopedia of Electrochemistry 2003, 1-53.

(32) Zhang, B. L. W.; Wang, Y. J.; Cheng, H. Y.; Yao, W. Q.; Zhu, Y. F. Synthesis of Porous $\mathrm{Bi}_{2} \mathrm{WO}_{6}$ Thin Films as Efficient Visible-Light-Active Photocatalysts. Adv. Mater. 2009, 21 (12), 1286-1290.

(33) Zhao, X.; Wu, Y.; Yao, W.; Zhu, Y. Photoelectrochemical Properties of Thin $\mathrm{Bi}_{2} \mathrm{WO}_{6}$ Films. Thin Solid Films 2007, 515 (11), 4753-4757.

(34) Kawazoe, H.; Yasukawa, M.; Hyodo, H.; Kurita, M.; Yanagi, H.; Hosono, H. P-type electrical conduction in transparent thin films of $\mathrm{CuAlO}_{2}$, Nature 1997, 839, 939-942.

(35) Scanlon, D. O.; Watson, G. W. $\left(\mathrm{Cu}_{2} \mathrm{~S}_{2}\right)\left(\mathrm{Sr}_{3} \mathrm{Sc}_{2} \mathrm{O}_{5}\right)$-A Layered, Direct Band Gap, p-Type Transparent Conducting Oxychalcogenide: A Theoretical Analysis, Chem. Mater. 2009, 21, 5435-5442 5435 .

(36) Hollingsworth, N.; Taylor, S. F. R.; Galante, M. T.; Jacquemin, J.; Longo, C.; Holt, K. B.; de Leeuw, N. H.; Hardacre, C. $\mathrm{CO}_{2}$ Capture and Electrochemical Conversion using Super Basic [P66614][124Triz], Faraday Discussions, 2015, 183, 389-400.

(37) Hollingsworth, N.; Taylor, S. F. R.; Galante, M. T.; Jacquemin, J.; Longo, C.; Holt, K. B.; de Leeuw, N. H.; Hardacre, C. Reduction of Carbon Dioxide to Formate at Low Overpotential using a Superbase Ionic Liquid. Angewandte Chemie, 2015, 54, 1416414168. 


\section{TOC Graphic}
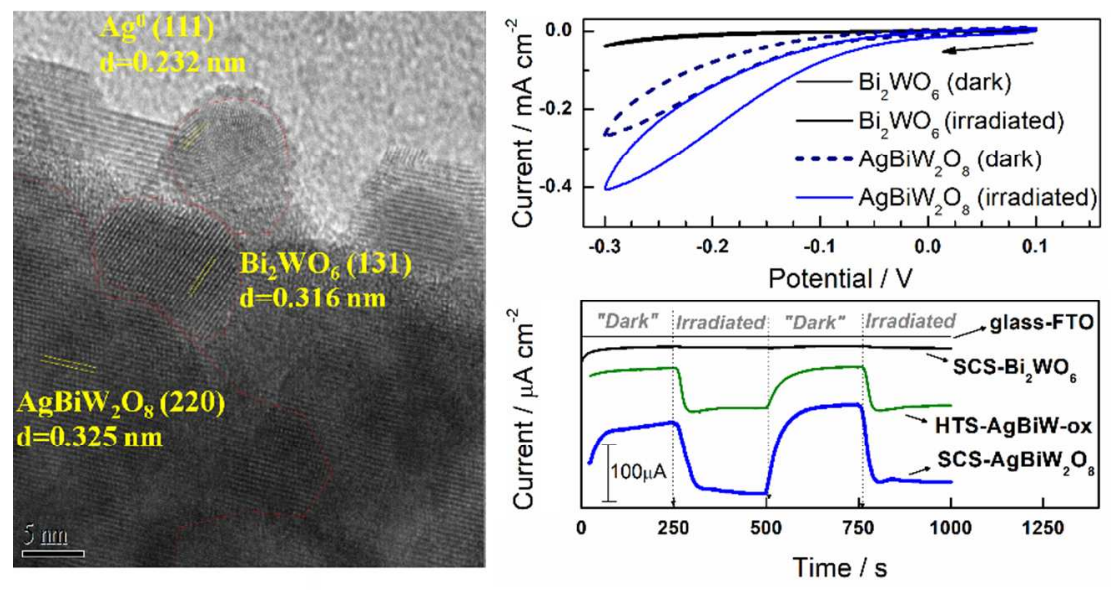